\title{
Financial Analysis as a Basis for Creation of the Financial Plan of the Selected Business Entity - Case Study
}

\author{
Pavol Skocdopole, ${ }^{1, *}$ \\ ${ }^{1}$ Slovak University of Agriculture in Nitra, Faculty of Economics and Management, Department of \\ Management, Tr. Andreja Hlinku 2, 94976 Nitra, Slovakia
}

\begin{abstract}
.
Research background: Authors mentioned in the Research describe a financial analysis as first step of a financial planning process. It is an effective tool in the evaluation of a company's financial efficiency on the basis of data from financial reports, where the individual data are sorted, aggregated and measured. The analysis usually consists liquidity, activity, profitability indicators and debt ratios. The result of the analysis should evaluate financial health and subsequently predict future of the focused company.

Purpose of the article: The scope of this article is a practical application of financial analysis of the company. The main sources of information include financial statements balance sheet and income statement over the period of the last 3 years. Other sources are information obtained from employees of the company and information gained by studying a literature. Methods: The analysis process begins by identifying the main objectives and targets, continues by the methodical procedure, analysis of indicators and an interpretation of the analysis results. The main objective of the analysis is to evaluate the assets, the sources and the overall economic situation of the company. The key indicators that are the status and development of current and non-current assets, the status and development of equity and liabilities and a profit development.

Findings \& Value added: The financial analysis of a focused company was applied for the last 3-year time period. The worst status of the indicators occurred in the second year and after the subsequent intervention of the company management the result improved to sustainable status.
\end{abstract}

Keywords: assets; equity; financial analysis; liabilities; profit

JEL Classification: $G 32 ; I 11 ; M 21$

*xskocdopole@uniag.sk 


\section{Introduction}

Planning is a process involving the establishment of organizational objectives, the selection of appropriate means and ways to achieve them and the definition of expected results at a specified time and at the required level. Strategic planning, a systematic approach to produce strategies with long-term thinking [1], [2] has proven to be an indispensable tool to generate effective decisions [3]. Financial planning is a process involving the creation of a company's financial objectives and a summary of measures and activities to achieve them. It is an integral part of a business plan and an important financial management tool. The result of financial planning is a financial plan [4].

\subsection{Financial-economics analysis}

Financial analysis is an effective tool in the evaluation of a company's financial efficiency on the basis of data from financial reports, where the individual data are sorted, aggregated and measured reciprocally [5]. Any financial decision-making must be supported with a financial analysis, the result of which forms the basis for management strategies of the company's structure, investment and pricing policy, stock management, etc. Credibility and bankruptcy models are generated with the goal of the quick orientation of investors and creditors with the view of evaluating the given company according to its quality, i.e. its trustworthiness and performance. The objective of credibility models is to provide an evaluation according to the level of the financial health, i.e. whether the quality of the company under evaluation is good or poor. The main problem to be solved in the company financing area is the relationship between company needs and financial resources. In this context, the following long-term decision-making processes need to be approved: Total needed capital, corporate capital structure, corporate assets structure, possibilities of alternative investment of corporate capital [6]. A detailed analysis of the company as a starting point for the creation of a financial plan was provided. It focuses not only on financial status, but also relations of financial and material aspects of the reproduction process in the company [7]. The indicator analysis provides a lot of useful information if the good judgment of the analyst is applied. Therefore, when calculating the indicators, it is necessary to look at the methods used in accounting, Financial indicators are used to assess the solvency, profitability and long-term outlook of the company [8]. Financial analysis should be understood as a process of analysis and evaluation, based on information sources from accounting data, but also from financial, non-financial, internal and external sources. Accounting sources include the financial statements: balance sheet, income statement and cash flow statement. Together they create a three-balance reporting system and complement each other. The quantification of financial indicators is followed by an objective evaluation. The homogeneity of the indicators has to be ensured for correct comparing, but they can occur at different times or at different places [9]. The main types of indicators of the financial-economic analysis include absolute and relative (ratio) indicators. The most important ratios are: liquidity indicators, activity indicators, profitability indicators, debt ratios, market value indicators [10], [11], [12]. Financial ratios rarely give answers, but help to ask the right questions. There are no international standards for these indicators. A reference point is needed to estimate the company's financial situation. It is useful to compare financial ratios with previous periods and with other firms in the same field [13]. Debt financial level is an important issue for every company. Every firm should find the optimal capital structure to maximize profitability and firm value. Due to financial debts are less expensive than equity, especially for the interest tax shields. On the other hand, it has been demonstrated that high debt increases the likelihood of insolvency [14]. The comparison of the accuracy of various prediction models and the decision which model has 
the highest prediction success rate was made. Following models were compared: Altman $Z^{\prime}$-score (1983), Altman $Z^{*}$ score (1995), Trustworthiness Index IN99 (2002), Trustworthiness Index IN05 (2002), Quicktest Kralicek (1993), Z-Score (1984), Taffler Model (1984), Credibility Index (1993), Index of Bonity (2001), Balance Analysis I. (1996), Classification Model (2006). The sample consisted of the total of 90 Czech companies, out of which $1 / 2$ were companies in bankruptcy and $1 / 2$ were non-bankrupt companies. When the individual models are compared based on the accuracy of classification, the highest total average accuracy was achieved by the Zmijewski model. The results show that the lowest error rate was achieved by Kralicek Quicktest. Both of the Zmijevski model and the Kralicek Quicktest had the highest predictive value during the global financial crisis [5]. A method for predicting the economic results of companies was found. There were used following methods for comparing 90 profitable companies and 93 bankrupt companies: Discriminant analysis, Logistic regression, Neural network [15]. There was created a systematic review method to create a guideline for the selection of an appropriate tool for developing a bankruptcy prediction model (BPM). There are so many tools that can be used to develop a BPM: Multiple Discriminant Analysis, Logistic regression, Neural Network, Support vector machines, Rough Sets, Case Based Reasoning, Decision Tree, Genetic Algorithm. The results of the methods can be provided to a differ users. So the methods were compared by 13 different criteria [16]. The predictive ability of the bankruptcy models formed in conditions of the Slovak economy in the sector of agriculture was verified. Eight prediction models (seven of them developed in the same economic environment in Slovakia and the Altman's Z score) were applied to the dataset of 3329 enterprises to compare the results with the best known bankruptcy model. The research findings confirm that the highest predictive ability of the bankruptcy prediction model is achieved in the same economic conditions and industrial sector in which they were primarily developed [17]. The theoretical aspects of financial architecture are analysed and it was found that the interpretation of this economic category is due to the existence of clear causal relationships between its constituent elements and their impact on the financial support. The definition of financial architecture is drawn as a set of interconnected structural elements such as capital structure, ownership structure and quality of corporate governance, which accumulate and mobilize financial resources, increase control over the activity of the enterprise, solve conflicts of interest between owners and other stakeholders. It is concluded that the construction of high-quality financial architecture is the basis of financial security of an enterprise, the level of which depends on the proper management of financial risks and ensuring an adequate level of safety of all its functional components. As a criterion for the effectiveness of the process of ensuring the financial security of the company, sustainable development of the enterprise was determined in the conditions of an unstable economic environment [18]. The limiting values of the financial stability of enterprises and the output of which allows the interpretation of this concept and its level were defined. Using the estimation model to determine the various enterprises' financial stability potentials, as calculated on the basis of the regression equation, can be determined the financial stability potential of enterprises via a numeric expression. It was possible to assess the quality of financial stability from the consideration of dynamics and structure, taking into account the variations of the indicators determining the quality of financial stability, to monitor indicators of financial stability potential, tracking, first of all, the most informative parameter of autonomy. Thus, the financial stability in relation to an individual enterprise can be considered as being the construction of such an internal system of organizing production and financial activities that ensure long-term activity in the market. This can be achieved through effective management of a company's assets using its own and other attracted sources of capital when environmental factors are variable the authors use the concept of financial stability, which is defined as follows: the ability of the 
company to continue to achieve its operational goals and fulfil its mission in the long term; the ability of the company to continue to achieve its operational goals and fulfil its mission in the long term; the ability of an enterprise to undertake continuous production and business activities within the market through the effective management of its financial resources, thus ensuring its creditworthiness and solvency; building an internal system of organizing production and financial activities, which ensures continuous activity in the market through balanced asset management, using both its own and attracted sources of capital when environmental factors are variable [19].

\section{Methods}

The main aim of the article is to use selected methods of economic and financial analysis to assess the economic situation of the company for the period of the last three years, its property and capital structure, development of costs and revenues, as well as external and internal factors that determined the mentioned indicators. The findings should be used for the creation of a financial plan for the next years. The main objective of the article is divided into the following partial, logically related objectives: characteristics of the company, assessment of the state, development and structure of assets, sources of coverage in the reporting period, in connection with this, an evaluation of the financing used for the company's solvency, assessment of profitability through synthetic indicators of the company, as well as other selected indicators used for assess the financial strength of the company assessment and potential resources for the recovering of long-term and short-term assets.

\subsection{Ex post financial analysis}

Liquidity indicators - They measure liquidity - the ability of a company to pay its debts on time.

Restricted stocks $=$ stock / sales (1); Restricted short-term receivables $=$ short-term receivables / sales (2); Restricted short-term liabilities = short-term liabilities / expense (3); Corrected stocks $=$ stocks. (1 - restricted stocks - restricted short-term receivables) (4); Adjusted short-term receivables $=$ short-term receivables. $(1$ - short-term receivables) (5); Adjusted current assets $=$ financial accounts + adjusted inventory + adjusted short-term receivables (6); Adjusted short-term liabilities = short-term liabilities. (1 - short-term commitments) (7); Available liquidity = financial accounts / short-term external capital (8); Current liquidity $=$ (financial accounts + short-term receivables) $/$ short-term external resources (9); Total liquidity $=$ (inventories + financial accounts + short-term receivables) $/$ short-term external capital (10); Operating liquidity = financial accounts / short-term liabilities (11); Current operating liquidity $=$ (financial accounts + short-term receivables $) /$ short-term liabilities (12); Total operating liquidity $=($ stocks + financial accounts + shortterm receivables) / short-term liabilities (13); Adjusted available liquidity = financial accounts / adjusted short-term liabilities (14); Adjusted current liquidity = (financial accounts + adjusted balance of receivables) / adjusted balance of short-term liabilities (15); Adjusted total liquidity $=$ adjusted balance of current assets / adjusted balance of current liabilities (16).

Indebtedness indicators - They measure the share of external capital in total capital.

Total indebtedness = external sources / total capital (17); Degree of self-financing = equity / total capital (18); Finance leverage = total capital / equity (19) Credit burden = bank loans and financial assistance / total capital (20); Interest coverage $=$ (gross profit $/$ loss + interest expense) / interest expense (21); Interest coverage with depreciation $=$ (gross profit + interest expense + depreciation) / depreciation expense (22); Insolvency $=$ short-term 
liabilities / short-term receivables (23); Financial profitability = profit / cash flow 1 (24); Cash flow $\mathrm{I}=$ Profit + depreciation - change in accruals on the assets side + change in accruals on equity and liabilities - changes in reserves (25); Cash flow II = Cash flow I Change in inventory (26); Cash flow III = Change in short-term receivables (27); Cash flow IV = Cash flow III + Change in short-term payables (28) [20].

\section{Results}

\subsection{Market situation, company description}

The analysed company is a subsidiary of a worldwide organization engaged in the research and development, production and sale of laboratory diagnostic analysers and reagents. The main source company income is the sale of laboratory diagnostic reagents used in human medicine. The company has been operating in Slovakia since 1994. Since the main income for companies in this market comes from the sale of reagents, this is adapted to the functioning of the market. By installing a closed system analyser, the customer actually commits to use the manufacturer's reagents, so these analysers are rent to the customer. The profit from the sale of reagents also covers the depreciation costs of the analyser. Open system analysers are offered for sale on the market so it is a source of business revenue. The prices on the market are mainly influenced by the prices of competitors and the value of payments of health insurance companies. Other factors influencing the customer's decision to purchase products are user comfort, quality of the service, quality of the reagents, flexibility of the logistics and customer service. A significant problem on the Slovak market is the high indebtedness of hospitals, where the average period of receivables collection is 1,5 years, in some cases 5 years.

\subsection{Ex post financial analysis}

The Ex-post financial analysis is aimed at assessing the status of the company in the past and its results are data for setting goals and strategies for the future. This analysis includes the following sections: analysis of the equity and capital structure; expense, revenue and profit / loss analysis; analysis of liquidity indicators; analysis of debt ratios. The state of the company's assets was affected mainly by the development of the economy in previous years and the events mentioned in the previous chapter. The company did not own any real estate or financial assets. They reside in rented premises, which was the decision of the foreign owner. The following tables provide an overview of the state and structure of assets, sources of coverage and economic outcome of the monitored company.

Table 1. State, development and structure of assets in $2017-2019$

\begin{tabular}{|l|c|c|c|c|c|c|c|c|c|c|}
\hline \multirow{2}{*}{ Indicator } & \multicolumn{4}{|c|}{ Indicator value } & \multicolumn{2}{c|}{ Change } & \multicolumn{2}{c|}{ Index } & \multicolumn{3}{c|}{ Structure } \\
\cline { 2 - 10 } & 2017 & 2018 & 2019 & $18-17$ & $19-18$ & $18 / 17$ & $19 / 18$ & $\begin{array}{c}\% \\
2017\end{array}$ & $\begin{array}{c}\% \\
2018\end{array}$ & $\begin{array}{c}\% \\
2019\end{array}$ \\
\hline $\begin{array}{l}\text { Total } \\
\text { assets }\end{array}$ & $\begin{array}{c}6752 \\
838\end{array}$ & $\begin{array}{c}9578 \\
544\end{array}$ & $\begin{array}{c}8621 \\
312\end{array}$ & $\begin{array}{c}2825 \\
706\end{array}$ & $\begin{array}{c}-957 \\
232\end{array}$ & 1,418 & 0,900 & 100,00 & 100,00 & 100,00 \\
\hline $\begin{array}{l}\text { Non- } \\
\text { current } \\
\text { assets }\end{array}$ & $\begin{array}{c}2482 \\
839\end{array}$ & $\begin{array}{c}3541 \\
949\end{array}$ & $\begin{array}{c}3412 \\
003\end{array}$ & $\begin{array}{c}1059 \\
110\end{array}$ & $\begin{array}{c}-129 \\
946\end{array}$ & 1,427 & 0,963 & 36,767 & 36,978 & 39,576 \\
\hline
\end{tabular}




\begin{tabular}{|c|c|c|c|c|c|c|c|c|c|c|}
\hline \begin{tabular}{|l} 
Intangible \\
assets
\end{tabular} & 0 & $\begin{array}{l}839 \\
189\end{array}$ & 656093 & $\begin{array}{l}839 \\
189\end{array}$ & $\begin{array}{c}-183 \\
096\end{array}$ & & 0,782 & 0,000 & 8,761 & 7,610 \\
\hline $\begin{array}{l}\text { Tangible } \\
\text { fixed } \\
\text { assets }\end{array}$ & $\begin{array}{c}2482 \\
839\end{array}$ & $\begin{array}{c}2702 \\
760\end{array}$ & $\begin{array}{c}2755 \\
910\end{array}$ & $\begin{array}{l}219 \\
921\end{array}$ & $\begin{array}{c}53 \\
150\end{array}$ & 1,089 & 1,020 & 36,767 & 28,217 & 31,966 \\
\hline $\begin{array}{l}\text { Long - } \\
\text { term } \\
\text { financial } \\
\text { assets }\end{array}$ & 0 & 0 & 0 & 0 & 0 & & & 0,000 & 0,000 & 0,000 \\
\hline \begin{tabular}{|l|}
$\begin{array}{l}\text { Current } \\
\text { assets }\end{array}$ \\
\end{tabular} & $\begin{array}{c}4259 \\
676\end{array}$ & $\begin{array}{c}6023 \\
336\end{array}$ & $\begin{array}{c}5205 \\
332\end{array}$ & $\begin{array}{c}1763 \\
660\end{array}$ & $\begin{array}{c}-818 \\
004\end{array}$ & 1,414 & 0,864 & 63,080 & 62,884 & 60,377 \\
\hline Inventory & $\begin{array}{c}59 \\
882\end{array}$ & $\begin{array}{l}180 \\
923\end{array}$ & 255307 & $\begin{array}{l}121 \\
041\end{array}$ & $\begin{array}{c}74 \\
384\end{array}$ & 3,021 & 1,411 & 0,887 & 1,889 & 2,961 \\
\hline \begin{tabular}{|l} 
Long - \\
term \\
receivables
\end{tabular} & $\begin{array}{c}49 \\
359\end{array}$ & $\begin{array}{l}132 \\
532\end{array}$ & 28216 & $\begin{array}{c}83 \\
173 \\
\end{array}$ & $\begin{array}{r}-104 \\
316\end{array}$ & 2,685 & 0,213 & 0,731 & 1,384 & 0,327 \\
\hline \begin{tabular}{|l|} 
Short - \\
term \\
receivables
\end{tabular} & $\begin{array}{c}4079 \\
765\end{array}$ & $\begin{array}{c}4246 \\
397\end{array}$ & $\begin{array}{c}4453 \\
313\end{array}$ & $\begin{array}{l}166 \\
632\end{array}$ & $\begin{array}{l}206 \\
916\end{array}$ & 1,041 & 1,049 & 60,416 & 44,332 & 51,655 \\
\hline $\begin{array}{l}\text { Financial } \\
\text { accounts }\end{array}$ & $\begin{array}{c}70 \\
670\end{array}$ & $\begin{array}{c}1463 \\
484\end{array}$ & 468496 & $\begin{array}{c}1392 \\
814\end{array}$ & $\begin{array}{c}-994 \\
988\end{array}$ & 20,709 & 0,320 & 1,047 & 15,279 & 5,434 \\
\hline \begin{tabular}{|l|} 
Time \\
distinction
\end{tabular} & $\begin{array}{c}10 \\
323\end{array}$ & $\begin{array}{c}13 \\
259\end{array}$ & 3977 & 2936 & $\begin{array}{c}-9 \\
282\end{array}$ & 1,284 & $\mathbf{0 , 3 0 0}$ & 0,153 & 0,138 & 0,046 \\
\hline
\end{tabular}

As we can see the highest assets were achieved in 2018, mainly because a competing company was bought worldwide by the surveyed company this year. Non-current assets increased intangible fixed assets (valued rights item) as a result of the creation of a new brand. The merger of these two global companies that complement each other's product portfolios created the opportunity to achieve a bigger market share not only by the merger itself, but also by providing global solutions to customers. Tangible fixed assets consist mainly of two types of assets - car fleet and laboratory analysers rent to laboratories. The condition of cars in the company is constant and renewed every 4 years, so there is no significant change in the volume of assets. As mentioned above, open system analysers are rent to hospitals to increase sales of diagnostic reagents. The need to continuously increase sales of goods depends on purchasing of the new analysers for rent, which increases the status of tangible fixed assets. Development of laboratory analysers is constantly upgrading, so it causes moral obsolescence on the analysers already in use. This causes procurement costs increasing for their regular renewal. Regarding current assets, the highest value item was receivables, which was caused by the low payment discipline of Slovak hospitals.

Table 2. State, development and structure of equity and liabilities in 2017 - 2019

\begin{tabular}{|l|c|c|c|c|c|c|c|c|c|c|}
\hline \multirow{2}{*}{ Indicator } & \multicolumn{3}{|c|}{ Indicator value } & \multicolumn{2}{c|}{ Change } & \multicolumn{2}{c|}{ Index } & \multicolumn{3}{c|}{ Structure } \\
\cline { 2 - 11 } & $\mathbf{2 0 1 7}$ & $\mathbf{2 0 1 8}$ & $\mathbf{2 0 1 9}$ & $\mathbf{1 8 - 1 7}$ & $\mathbf{1 9 - 1 8}$ & $\mathbf{1 8 / 1 7}$ & $\mathbf{1 9 / 1 8}$ & $\mathbf{\%} 2017$ & $\% \mathbf{2 0 1 8}$ & $\mathbf{\%} 2019$ \\
\hline $\begin{array}{l}\text { Total } \\
\text { equity } \\
\text { and } \\
\text { liabilities }\end{array}$ & $\begin{array}{c}\mathbf{6 7 5 2} \\
\mathbf{8 3 8}\end{array}$ & $\begin{array}{c}\mathbf{9 5 7 8} \\
\mathbf{5 4 4}\end{array}$ & $\begin{array}{c}\mathbf{8 6 2 1} \\
\mathbf{3 1 2}\end{array}$ & $\begin{array}{c}\mathbf{2} \mathbf{8 2 5} \\
\mathbf{7 0 6}\end{array}$ & $\begin{array}{c}\mathbf{- 9 5 7} \\
\mathbf{2 3 2}\end{array}$ & $\mathbf{1 , 4 1 8}$ & $\mathbf{0 , 9 0 0}$ & $\mathbf{1 0 0 , 0 0}$ & $\mathbf{1 0 0 , 0 0}$ & $\mathbf{1 0 0 , 0 0}$ \\
\hline Equity & $\mathbf{- 2 7 5}$ & $\mathbf{- 1 4 5 2}$ & $\mathbf{3 4 7 0}$ & $\mathbf{- 1 1 7 7}$ & $\mathbf{4 9 2 2}$ & $\mathbf{5 , 2 7 7}$ & $\mathbf{- 2 , 3 9 0}$ & $\mathbf{- 4 , 0 7 5}$ & $\mathbf{- 1 5 , 1 6 1}$ & $\mathbf{4 0 , 2 5 3}$ \\
\hline Capital & 13 & 13 & 13 & 0 & 0 & 1,000 & 1,000 & 0,197 & 0,139 & 0,154 \\
\hline
\end{tabular}




\begin{tabular}{|l|c|c|c|c|c|c|c|c|c|c|} 
& 278 & 278 & 278 & & & & & & & \\
\hline $\begin{array}{l}\text { External } \\
\text { sources }\end{array}$ & $\begin{array}{c}\mathbf{7 0 2 8} \\
\mathbf{0 1 6}\end{array}$ & $\begin{array}{c}\mathbf{1 1} \\
\mathbf{0 2 9} \\
\mathbf{9 2 5}\end{array}$ & $\begin{array}{c}\mathbf{5 1 3 1} \\
\mathbf{0 1 5}\end{array}$ & $\begin{array}{c}\mathbf{4} \mathbf{0 0 1} \\
\mathbf{9 0 9}\end{array}$ & $\begin{array}{c}\mathbf{- 5 8 9 8} \\
\mathbf{9 1 0}\end{array}$ & $\mathbf{1 , 5 6 9}$ & $\mathbf{0 , 4 6 5}$ & $\mathbf{1 0 4 , 0 7}$ & $\mathbf{1 1 5 , 1 5}$ & $\mathbf{5 9 , 5 1 5}$ \\
\hline Reserves & $\begin{array}{c}70 \\
670\end{array}$ & $\begin{array}{c}173 \\
710\end{array}$ & $\begin{array}{c}76 \\
943\end{array}$ & $\begin{array}{c}103 \\
040\end{array}$ & $\begin{array}{c}-96 \\
767\end{array}$ & 2,458 & 0,443 & 1,047 & 1,814 & 0,892 \\
\hline $\begin{array}{l}\text { Long- } \\
\text { term } \\
\text { liabilities }\end{array}$ & 0 & 151 & 3627 & 151 & 3476 & & 24,02 & 0,000 & 0,002 & 0,042 \\
\hline $\begin{array}{l}\text { Short - } \\
\text { term } \\
\text { liabilities }\end{array}$ & $\begin{array}{c}6957 \\
346\end{array}$ & $\begin{array}{c}10 \\
856\end{array}$ & $\begin{array}{c}5050 \\
445\end{array}$ & $\begin{array}{c}3898 \\
718\end{array}$ & $\begin{array}{c}-5805 \\
619\end{array}$ & 1,560 & 0,465 & 103,028 & 113,337 & 58,581 \\
\hline $\begin{array}{l}\text { Bank } \\
\text { loans }\end{array}$ & 0 & 0 & 0 & 0 & 0 & & & 0,000 & 0,000 & 0,000 \\
\hline
\end{tabular}

The structure of the sources of coverage corresponds to the market situation. The high value of receivables on the assets side is reflected in the liability side by the high value of liabilities. Secondary insolvency appears and hospital debts are transferred to the external parent company. As described above, a competing company was purchased in 2018. Own sources of the company were not enough to cover this purchase, therefore foreign owners had to invest $€ 4160834$ into the Slovakian company, which caused an increase in the external resources in Payables to controlled entity and controlling entity. Regarding equity and liabilities, 2019 was significantly more positive than 2018, equity increased and liabilities decreased, mainly as a result of an increase in capital funds, a decrease in the volume of money in financial accounts and a positive economic result. The combination of the loss and high receivables in 2018 endangered the operation of the company. Therefore, in 2019 foreign owners were forced to invest $€ 4,000,000$ into the company's capital funds.

Table 3. State, development and structure of expenses in 2017 - 2019

\begin{tabular}{|l|c|c|c|c|c|c|c|c|c|}
\hline \multirow{2}{*}{ Indicator } & \multicolumn{3}{|c|}{ Indicator value } & \multicolumn{3}{c|}{ Change } & \multicolumn{3}{c|}{ Index } \\
\cline { 2 - 10 } & $\mathbf{2 0 1 7}$ & $\mathbf{2 0 1 8}$ & $\mathbf{2 0 1 9}$ & $\mathbf{1 8 - 1 7}$ & $\mathbf{1 9 - 1 8}$ & $\mathbf{1 9 - 1 7}$ & $\mathbf{1 8} / \mathbf{1 7}$ & $\mathbf{1 9 / 1 7}$ & $\mathbf{1 9 / 1 8}$ \\
\hline $\begin{array}{l}\text { Economic } \\
\text { expenses }\end{array}$ & 5107581 & 7007052 & 5360526 & 1899471 & $\begin{array}{c}- \\
646526\end{array}$ & 252945 & 1,37 & 1,05 & 0,77 \\
\hline $\begin{array}{l}\text { Financial } \\
\text { expenses }\end{array}$ & 146153 & 135726 & 158265 & -10427 & 22539 & 12112 & 0,93 & 1,08 & 1,17 \\
\hline $\begin{array}{l}\text { Exceptional } \\
\text { expenses }\end{array}$ & 0 & 0 & 0 & 0 & 0 & 0 & & & \\
\hline Total expenses & 5253734 & 7142778 & 5518791 & 1889044 & $\begin{array}{c}- \\
623987\end{array}$ & 265057 & 1,36 & 1,05 & 0,77 \\
\hline
\end{tabular}

Table 4. State, development and structure of revenue in 2017 - 2019

\begin{tabular}{|l|c|c|c|c|c|c|c|c|c|}
\hline \multirow{2}{*}{ Indicator } & \multicolumn{3}{|c|}{ Indicator value } & \multicolumn{3}{c|}{ Change } & \multicolumn{3}{c|}{ Index } \\
\cline { 2 - 10 } & $\mathbf{2 0 1 7}$ & $\mathbf{2 0 1 8}$ & $\mathbf{2 0 1 9}$ & $\mathbf{1 8 - 1 7}$ & $\mathbf{1 9 - 1 8}$ & $\mathbf{1 9 - 1 7}$ & $\mathbf{1 8 / 1 7}$ & $\mathbf{1 9 / 1 7}$ & $\mathbf{1 9 / 1 8}$ \\
\hline $\begin{array}{l}\text { Economic } \\
\text { revenue }\end{array}$ & 4764987 & 5936143 & 6443746 & 1171156 & 507603 & 1678759 & 1,25 & 1,35 & 1,09 \\
$\begin{array}{l}\text { Financial } \\
\text { revenue }\end{array}$ & 913463 & 29633 & 515 & -883830 & -29118 & -912948 & 0,03 & 0,00 & 0,02 \\
\hline $\begin{array}{l}\text { Exceptional } \\
\text { revenue }\end{array}$ & 0 & 0 & 0 & 0 & 0 & 0 & & & \\
\hline $\begin{array}{l}\text { Total } \\
\text { revenue }\end{array}$ & 5678451 & 5965776 & 6444261 & 287325 & 478485 & 765810 & 1,05 & 1,13 & 1,08 \\
\hline
\end{tabular}


Table 5. State, development and structure of profit in 2017 - 2019

\begin{tabular}{|c|c|c|c|c|c|c|c|c|c|}
\hline \multirow[t]{2}{*}{ Indicator } & \multicolumn{3}{|c|}{ Indicator value } & \multicolumn{3}{|c|}{ Change } & \multicolumn{3}{|c|}{ Index } \\
\hline & 2017 & 2018 & 2019 & $18-17$ & $19-18$ & 19-17 & $18 / 17$ & $19 / 17$ & $19 / 18$ \\
\hline Economic profit & $\begin{array}{c}-342 \\
594\end{array}$ & $\begin{array}{c}-1070 \\
909\end{array}$ & $\begin{array}{c}1083 \\
220\end{array}$ & $\begin{array}{l}-728 \\
315\end{array}$ & $\begin{array}{c}2154 \\
129\end{array}$ & $\begin{array}{c}1425 \\
814\end{array}$ & 3,13 & $-3,16$ & $-1,01$ \\
\hline Financial profit & $\begin{array}{l}767 \\
311\end{array}$ & $\begin{array}{l}-106 \\
093\end{array}$ & $\begin{array}{c}-157 \\
750\end{array}$ & $\begin{array}{l}-873 \\
404\end{array}$ & -51657 & $\begin{array}{c}-925 \\
061\end{array}$ & $-0,14$ & $-0,21$ & 1,49 \\
\hline $\begin{array}{l}\text { Exceptional } \\
\text { profit }\end{array}$ & 0 & 0 & 0 & 0 & 0 & 0 & & & \\
\hline Total profit & $\begin{array}{l}424 \\
716\end{array}$ & $\begin{array}{c}-1177 \\
002\end{array}$ & $\begin{array}{l}922 \\
565\end{array}$ & $\begin{array}{c}-1601 \\
718\end{array}$ & $\begin{array}{c}2099 \\
567\end{array}$ & $\begin{array}{l}497 \\
849\end{array}$ & $-2,77$ & 2,17 & $-0,78$ \\
\hline
\end{tabular}

In the area of costs and revenues, the biggest role was played by the expenses and revenues from economic activity, mainly revenues from the sale of goods, costs of their purchase and depreciation of tangible fixed assets. Revenue from the sale of goods and depreciation of fixed assets tended to increase, which is in line with expectations. But in 2019 the procurement cost was reduced, which also significantly influenced the positive economic result this year. This was achieved by reducing the purchase price of the goods by agreement with the parent company. Financial profit was influenced mainly by exchange rate differences between the purchase of goods and later payments of liabilities.

Table 6. Liquidity indicators development in 2017 - 2019

\begin{tabular}{|l|c|c|c|c|c|c|c|c|c|}
\hline \multirow{2}{*}{ Indicator } & \multicolumn{3}{|c|}{ Indicator value } & \multicolumn{3}{c|}{ Change } & \multicolumn{3}{c|}{ Index } \\
\cline { 2 - 11 } & $\mathbf{2 0 1 7}$ & $\mathbf{2 0 1 8}$ & $\mathbf{2 0 1 9}$ & $\mathbf{1 8 - 1 7}$ & $\mathbf{1 9 - 1 8}$ & $\mathbf{1 9 - 1 7}$ & $\mathbf{1 8 / 1 7}$ & $\mathbf{1 9 / 1 7}$ & $\mathbf{1 9 / 1 8}$ \\
\hline Total liquidity & 0,61 & 0,54 & 1,03 & 0,42 & 0,48 & $-0,06$ & 1,69 & 1,89 & 0,90 \\
\hline Current liquidity & 1,01 & 1,13 & 1,09 & 0,08 & $-0,04$ & 0,12 & 1,08 & 0,96 & 1,12 \\
\hline Available liquidity & 0,01 & 0,13 & 0,09 & 0,08 & $-0,04$ & 0,12 & 9,13 & 0,69 & 13,27 \\
\hline Operational total liquidity & 0,61 & 0,54 & 1,03 & 0,42 & 0,48 & $-0,06$ & 1,69 & 1,89 & 0,90 \\
\hline $\begin{array}{l}\text { Operational current } \\
\text { liquidity }\end{array}$ & 0,60 & 0,53 & 0,97 & 0,38 & 0,45 & $-0,07$ & 1,63 & 1,85 & 0,88 \\
\hline $\begin{array}{l}\text { Operational available } \\
\text { liquidity }\end{array}$ & 0,01 & 0,13 & 0,09 & 0,08 & $-0,04$ & 0,12 & 9,13 & 0,69 & 13,27 \\
\hline Adjusted total liquidity & $-0,12$ & $-0,19$ & $-0,79$ & $-0,67$ & $-0,60$ & $-0,07$ & 6,44 & 4,11 & 1,57 \\
\hline Adjusted current liquidity & $-0,12$ & $-0,19$ & $-0,76$ & $-0,64$ & $-0,57$ & $-0,07$ & 6,30 & 4,04 & 1,56 \\
\hline $\begin{array}{l}\text { Adjusted available } \\
\text { liquidity }\end{array}$ & $-0,02$ & $-0,10$ & $-0,21$ & $-0,19$ & $-0,10$ & $-0,09$ & 13,88 & 2,01 & 6,92 \\
\hline
\end{tabular}

Available liquidity in 2019 exceeded the recommended value 0.8, which indicates a high ratio of financial accounts to short-term external capital. Current liquidity was within the recommended range. The total liquidity in the period under review was below the recommended value of 1.5 , which represents a low value of current assets compared to short-term external capital. Operational current liquidity was below the recommended value, but the trend is positive. Operational total liquidity and operational available liquidity were also below the recommended level, which was due to the high value of shortterm liabilities. As already mentioned, the high level of liabilities in this case does not cause the company's operational problems. Adjusted liquidity values were negative due to the high level of short-term liabilities. 
Table 7. Indebtedness indicators development in 2017 - 2019

\begin{tabular}{|c|c|c|c|c|c|c|c|c|c|}
\hline \multirow{2}{*}{ Indicator } & \multicolumn{3}{|c|}{ Indicator value } & \multicolumn{3}{|c|}{ Change } & \multicolumn{3}{|c|}{ Index } \\
\hline & 2017 & 2018 & 2019 & $\begin{array}{l}18- \\
17\end{array}$ & $19-18$ & $\begin{array}{l}19- \\
17\end{array}$ & $18 / 17$ & $19 / 17$ & $19 / 18$ \\
\hline Total debt & 1,04 & 1,15 & 0,60 & $-0,45$ & $-0,56$ & 0,11 & 0,57 & 0,52 & 1,11 \\
\hline Degree of self - financing & $-0,04$ & $-0,15$ & 0,40 & 0,44 & 0,55 & $-0,11$ & $-9,88$ & $-2,66$ & 3,72 \\
\hline Financial leverage & $\begin{array}{c}- \\
24,54\end{array}$ & $-6,60$ & 2,48 & 27,02 & 9,08 & 17,94 & $-0,10$ & $-0,38$ & 0,27 \\
\hline Credit burden & 0,00 & 0,00 & 0,00 & 0,00 & 0,00 & 0,00 & & & \\
\hline Interest coverage & & $\begin{array}{c}- \\
126,89\end{array}$ & 23,82 & & 150,72 & & & $-0,19$ & \\
\hline $\begin{array}{l}\text { Interest coverage } \\
\text { including depreciation }\end{array}$ & & $-30,88$ & 51,91 & & 82,80 & & & $-1,68$ & \\
\hline Insolvency & 1,71 & 2,56 & 1,13 & $-0,57$ & $-1,42$ & 0,85 & 0,67 & 0,44 & 1,50 \\
\hline
\end{tabular}

The recommended debt is $50-70 \%$ in according to the literature. In this case, the total indebtedness in 2017 and 2018 exceeds $100 \%$ of the total capital of the company, but this does not cause operational difficulties for the company, since the external sources are liabilities to a foreign parent that will not demand repayment of liabilities at the expense of the company. In 2019 , the company has already reached the value of $60 \%$, mainly due to the increase in capital funds. The financial leverage indicator has a positive trend, which can also be said about the interest coverage, which was mainly influenced by the positive economic result in 2019.

\section{Discussion}

Using the methods of investigation mentioned in the Data and Methods of the article and their elaboration in the section Results and Discussion, the following conclusions were found: The highest assets were achieved in 2018, which was caused by the purchase of a competitor and the subsequent merger. In 2019 there was a decrease in assets due to a decrease in current and non-current assets, the main reason of which was a decrease in the balance of financial accounts; The structure of the sources of coverage corresponded to the market situation. The high volume of receivables on the assets side was reflected in the liability side by a high value of liabilities that the company was unable to pay. The purchase of a competing company in 2018 caused a further increase in liabilities to the parent company, which had to provide the sources necessary to carry out the deal. In 2019, the bad economic result and the high level of receivables from the previous year required next investment of the parent's company to the capital funds, which led to an increase in equity and thus a decreasing of total debt; A specific feature of the healthcare sector in Slovakia is the increase in hospital debts and the extension of the period of collection of receivables. Paying debts of hospitals by government in 2018 reduced collection period for receivables to 262 days; In view of the increasing value of receivables each year, depending on the planned increase in sales, we proposed measures to reduce them by employing a part-time employee whose task will be to collection and communication these receivables from hospitals.

\section{References}

1. Grunig, R., Kuhn, R. (2010). Process-based strategic planning (6th ed.). Dordrecht: Springer. 
2. Ioppolo, G., Cucurachi, S., Salomone, R., Saija, G., Shi, L. (2016). Sustainable local development and environmental governance: A strategic planning experience. Sustainability, 8(2), 180.

3. Bryson, J. M. (2018). Strategic planning for public and nonprofit organizations: A guide to strengthening and sustaining organizational achievement. John Wiley \& Sons.

4. Pinkova, D., Neumanova, A. (1996). Podnikova Ekonomika. 1 vydanie. Bratislava: Vydavatelske oddelenie Pravnickej fakulty UK v Bratislave, 231.

5. Pech, M., Prazakova, J., \& Pechova, L. (2020). The Evaluation of the Success Rate of Corporate Failure Prediction in a Five-Year Period. Journal of Competitiveness, 12(1), 108.

6. Cernohorsky, J., Teply, P. (2011). Zaklady financi. Prve vydanie. Praha: GRADA Publishing, a.s., 2011. 304.

7. Vlachynsky, K., et al. (2009). Podnikove Financie. Prve vydanie. Bratislava : IURA EDITION, spol. s r. o., 524.

8. Komornik, J., Majercakova, D., Husovska, M. (2011). Financny manazment. Prve vydanie. Bratislava: KARTPRINT, 251.

9. Bielik, P. (2008). Podnikove hospodarstvo. Druhe vydanie. Nitra: Slovenska polnohospodarska univerzita v Nitre, 2008. 319 s. ISBN 978-80-552-0010-1.

10. Gurcik, L. (2004). Podnikatelska analyza a kontroling. Slovenska polnohospodarska univerzita.

11. Fotr, J. (1999). Strategické finanční plánování. Grada.

12. Strokovych, G. V., \& Mykolenko, O. P. (2018). Formation of the system of assessments of the financial and investment potential of an enterprise. Financial and credit activity: problems of theory and practice, 2(25), 246-252.

13. Brealey, R A., Myers, S C. (2000). Teorie a praxe firemních financi. Praha: Computer Press, 2000. 1064 s. ISBN 80-7226-189-4.

14. Correa-Mejia, D. A., \& Lopera-Castano, M. (2020). Financial ratios as a powerful instrument to predict insolvency; a study using boosting algorithms in Colombian firms. Estudios Gerenciales, 36(155), 229-238.

15. Dvoracek, J., Sousedikova, R., Repka, M., Domaracka, L., Bartak, P., Bartosikova, M. (2012). Choosing a method for predicting economic performance of companies. Metalurgija/Metallurgy, 51(4), 525-528.

16. Alaka, H. A., Oyedele, L. O., Owolabi, H. A., Kumar, V., Ajayi, S. O., Akinade, O. O., \& Bilal, M. (2018). Systematic review of bankruptcy prediction models: Towards a framework for tool selection. Expert Systems with Applications, 94, 164-184.

17. Valaskova, K., Durana, P., Adamko, P., \& Jaros, J. (2020). Financial Compass for Slovak Enterprises: Modeling Economic Stability of Agricultural Entities. Journal of Risk and Financial Management, 13(5), 92.

18. Sosnovska, O., \& Zhytar, M. (2018). Financial architecture as the base of the financial safety of the enterprise. Baltic Journal of Economic Studies, 4(4), 334-340.

19. Natocheeva, N., Borodin, A., Rud, N., Kutsuri, G., Zholamanova, M., \& Namitulina, A. (2019). Development of tools for realizing the potential of financial stability of enterprises. Entrepreneurship and Sustainability Issues, 7(2), 1654-1665.

20. Gurcik, L., Miklovicova, J. (2009). Priklady na cvicenia z financno-ekonomickej analyzy. Prve vydanie. Nitra: Vydavatelstvo SPU v Nitre, 2009. 76 s. ISBN 978-80552-0296-9. 